\title{
DETERMINANTS OF MIGRATION FOLLOWING THE EU ENLARGEMENT: A PANEL DATA ANALYSIS
}

Sanja Franc, Anita Čeh Časni, Antea Barišić

\section{ABSTRACT}

The Eastern enlargements of the European Union (EU) since the early 2000s have included post-transitional economies at a lower level of development than the existing member states and thus, have significantly affected the East-West migration flows and labour markets on both sides. This has provided a distinctive opportunity to study the effects of liberalisation and to identify economic factors leading to migration flows with the purpose of enabling better estimations of future migration trends. In this research, a panel data analysis with pair of country fixed effects and time fixed effects is used to explore several pull and push factors of the East-West EU migration flows in the period from 2000 to 2017. Results indicate that emigration rate responds rather quickly to the changes in GDP per capita and unemployment rate of the youth population in immigration country, with statistically significant elasticity coefficients, suggesting that international migration contributes significantly to adjusting the labour supply to fluctuations in economic activity.

Key words: migration determinants, youth unemployment, EU enlargement, panel data analysis.

JEL: F22, C01

\section{INTRODUCTION}

Migration has a significant role in the global integration process, together with international trade and foreign direct investment, but unlike the latter, migration still hasn't experienced liberalisation on a global level during the last few decades. Migration motives are generally divided into three groups: economic, political and socio-cultural, where different 'push' factors in the country of emigration and 'pull' factors in the country of immigration can be recognised. The most common push factors are poverty, unemployment, low wages, high fertility rates, lack of basic health and education. On the other hand, most common pull factors in the country of immigration are prospects of higher wages, opportunities for an improved standard of living and personal or professional development (Fan and Stark 2007). The simplest economic models of migration explain that motivation for migration
Sanja Franc, PhD

Assistant Professor

Faculty of Economics and Business

University of Zagreb

E-mail: sfranc@efzg.hr

Anita Čeh Časni, PhD

Assistant Professor

Faculty of Economics and Business

University of Zagreb

E-mail: aceh@efzg.hr

\section{Antea Barišić, MA}

Teaching and Research Assistant

Faculty of Economics and Business

University of Zagreb

E-mail: abarisic@efzg.hr 
comes from real wage differentials across countries that emerge from various degrees of labour market rigidity, while there are also models showing that migration is driven by expected rather than real wage differentials (Mansoor and Quillin 2006). Depending on the sample of countries, time period and used methods, studies point out to different importance of push and pull factors.

After 1989, Europe began to face significant intraregional migratory movements. Freedom of movement obtained by the Central and Eastern European citizens has generated large migratory movements from the East to the West (Panzaru 2013). Atoyan et al. (2016) estimated that about $5.5 \%$ of the population of Southeast and Central Europe have left this region in the period from 1988 to 2012. Enlargements of the European Union since the early 2000s, which have included emerging economies, have considerably affected the state of the labour markets and stock of migrants in the EU. Exploring the direction, intensity and determinants of those migration flows is necessary to understand the potential effects on both the origin and the destination country. Thus, the East-West EU migration has become a significant topic in migration studies (Favell 2008).

Previous research has shown that the main migration determinants in the EU were more connected to the labour market (Kahanec and Zimmerman 2010) rather than social benefits (Giulietti et al. 2011), thus confirming the neoclassical theory of migration. Kahanec, Pytlikova, and Zimmermann (2014) also emphasise the effects of business cycles in destination countries on migration flows.

This study contributes to the literature by identifying the importance of selected economic determinants that lead to migration flows in the contemporary context, given the fact that scholars emphasise differences among migration determinants in different periods and settings. It contributes especially to the research of migration effects deriving from the latest EU enlargements where new member states significantly differ in economic and other properties to the old ones. Given the range of economic cycle periods and including all new member states, this research can enable better estimations of the future migration flows and the creation of policies that could affect them. It also emphasises youth unemployment (young population between 15 and 24 years old) in both origin and destination countries as an important migration determinant. Young people are seen as drivers of change in their societies and emigration of this group can particularly affect the emigration countries. At the same time, there is a lack of empirical evidence on the importance of their unemployment ratios to migration decision.

The main objective of this paper is to empirically examine several 'push' and 'pull' factors to determine their effects on migration flows from the 'new' EU member states to the 'old' EU member states that differ significantly in economic and other characteristics, which is precisely the aspect that makes these Eastern enlargements different from the previous ones. Unemployment is a persistent issue in most of the new EU member states, but young people are affected particularly hard as the EU youth unemployment rate is more than double the overall unemployment rate and differs considerably among countries. Thus, besides examining GDP per capita, unemployment rate, and EU membership as determinants of migration, we also analyse the youth unemployment rate as a determining factor of migration flows. While some of the previous studies (Mayda 2005; Kim and Cohen 2010) have included the share of young people in the total population as a migration determinant, the additional contribution of this research is in examining the significance of youth unemployment rate in determining the emigration rate.

The research is divided into five parts, as follows. Literature review on migration determinants in section 2 points out to different push and pull factors, each ranging from economic to social and political ones. Examining the significance of selected economic push and pull factors within the two groups of the EU member states was the primary motivation for this paper. Section 3 includes the empirical analysis which was conducted using a panel data analysis with pair of country fixed effects and time fixed effect including several pull and push factors of migration flows. More precisely, data on yearly immigrant inflows into 15 developed European countries by country of origin was used to empirically test which determinants of migration flows affect emigration rate the most. The analysis included the period from 2000 to 2017, thus encompassing the effects of the financial crisis and the postcrisis period. Fixed effect panel model is employed with country and time specific effects to avoid biased estimates. Also, regressions have robust standard errors clustered by country pair (destination and origin country), to address heteroscedasticity and allow for correlation over time of country pair observations. Section 4 presents results of the empirical analysis which indicate that emigration rate responds rather quickly to changes in GDP per capita and unemployment rate of young population in immigration country, with statistically significant elasticity coefficients, suggesting that international migration contributes significantly to adjusting the labour supply to fluctuations in economic activity. The conclusions of the 
analysis in section 5 lead to a better understanding of the EU migration flows determinants, as an essential prerequisite for estimating future migration flows. Emigration rate responds rather quickly to changes in GDP per capita and unemployment rate of the youth population in immigration country, with statistically significant elasticity coefficients. Also, EU membership as a dummy variable has shown to affect migration.

\section{LITERATURE REVIEW}

International migration represents an integral part of global flows. Different determinants are leading to the decision on migration, reaching from economic, social, cultural, political to ecological and other, but one of the main motives is often the aspiration of migrants to improve their livelihood (Hatton and Williamson 2005). Even in the early works in this area (for example, Lee 1966), special attention was given to differences in the level of development between areas, differences in population characteristics and the ease of overcoming migration obstacles. Thus, we can distinguish between 'push' factors in the country of emigration and 'pull' factors or desirable factors in the country of immigration (Dorigo and Tobler 1983). Besides the already mentioned ones, these factors may include differences in wages in certain sectors, unemployment rates, opportunities for personal and professional advancement, better living conditions, freedom, climate conditions and other factors that push migrants from the country of emigration and pull them to destination countries (Jurčić and Barišić 2018).

Migration determinants are recognized as an important research topic, but studies reveal different results depending on the time-frame, sample of countries and methods applied in the research. Various studies point out a set of economic and demographic factors as being the most important ones while explaining the migration process among different samples of developed and less developed countries in different parts of the world. Also, migration costs deriving from the geographical distance and cultural differences are shown to be important in determining migration flows.

Mayda (2005) used annual panel data set on the sample of the OECD countries from 1980 to 1995 , while focusing on both supply and demand determinants of migration patterns, and found results broadly consistent with the theoretical predictions of the standard international migration model. Namely, the results have shown that pull factors, which include improvements in the income opportunities in the destination country, significantly increase the immigration rates. Oh and Jung (2013) while investigating migration flows in South Korea in the period from 1993 to 2011, suggest that economic development accelerates emigration flows as it decreases financial restrictions to migration. They also revealed that volume of trade, as evidence of an economic link between countries, is an important predictor of the size and composition of foreign migrant population, while speculating that this influence is due to information effects and foreign labour policy channel.

Besides GDP per capita and real wage per hour, as important economic determinants, Sulaimanova and Bostan (2014) pointed to depreciation of local currencies and labour force growth in Tajikistan and Kyrgizstan, as countries of origin, in determining their emigration to Russian Federation in the period from 1998 to 2011 . Also, remittances that are usually investigated in the studies of migration effects have shown to be an important incentive that encourages further emigration in some cases (Wickramasinghe and Wimalaratana 2016; Sulaimanova and Bostan 2014). Furthermore, social remittances are shown to enable mobility through sharing ideas, practices and narratives (Levitt and Lamba-Nieves 2011) that can be addressed through micro-level studies.

Economic theory also emphasises the importance of personal taxation on migration, especially among groups of high-income workers and professionals, but empirical studies covering this topic are very limited. Challenges in measuring this relationship are mostly regarded to limited data availability. Thus, most of the existing studies are done at the micro-level, including only specific groups (usually those with the highest income) or only several developed countries that record in-detail administrative data (Kleven et al. 2019).

Several studies also point out to negative effects of migration costs. Migration cost is usually measured as the distance between capital cities of origin and destination country and is reported to be an important determinant of migration flows (Mayda 2005; Mayda 2010; Kim and Cohen 2010).

Demographic factors are considered to be closely related to economic ones, and some of the demographic factors are even used as proxies for economic or living conditions (Kim and Cohen 2010). Studies including different country samples call attention to demographic characteristics as important in determining the migration flows. Oh and Jung (2013) suggest that demographic factors, especially ageing population of developed countries, have an impact on migration flows, while Kim and Cohen (2010) point out demographics (log population of origin and destination and log infant mortality rate (IMR) of origin and 
destination) as one of the most significant variables in affecting the flows among selected developed countries between 1950 and 2007. Oh and Jung (2013) also reveal different patterns for skilled and unskilled migrant workers.

Mayda (2010) found that the share of the young population in the origin country had a positive and significant impact on emigration rates in case of the OECD countries in the period from 1980 to 1995. Focusing on developed countries in the period from 1950 to 2007, Kim and Cohen (2010) found that increased youth population share in the destination country was associated with lower inflows, while the increasing youth population share in the origin country was associated with higher inflows. Efendic (2015) also showed the importance of being young as one of the most significant individual characteristics in determining future emigration in Bosnia and Hercegovina in the period from 2002 to 2010, which is in line with the prior literature.

While neoclassical migration theory emphasises economic determinants and excludes social and political dimensions (Wickramasinghe and Wimalaratana 2016), other studies show that wage and employment differentials were statistically significant predictors of migration in the expected directions only about half the time (Mansoor and Quillin 2006), which means that other non-economic factors are also important in explaining migration. Migration flows change with the altering socioeconomic and geopolitical conditions (Wickramasinghe and Wimalaratana 2016) and the most important non-economic determinants are social and political factors shaping the migration process.

A broad stream of literature emphasises that social relationships have a significant effect on migration. At the centre of sociological research are migration networks which can be defined as 'set of interpersonal ties that connect migrants, former migrants and nonmigrants in origin and destination areas through ties of kinship, friendship and shared community origin' (Massey et al. 1993, p. 448). Migrant networks have been emphasised as an important factor in labour migration in both developed and developing countries as they reduce migration costs (Zhao 2003). They are thought to drive continuous migration flows, not depending on economic and other factors that might have caused the initial flows (Liu 2013; Garip and Asad 2015). Also, there is a potential brain gain through these networks, especially in cases of forming expatriate knowledge networks (Meyer 2001). However, migrant networks are usually researched using survey data that are not very common among countries. They do not allow for a broader study as there is no universal framework of collecting these data (Zhao 2003) and even if collected, only a limited amount of data is available (Haug 2008). In-depth qualitative studies on smaller samples are made to examine it, but there is a need for structuring the process and interviews in both origin and destination countries to analyse these effects (Haug 2008). Morover, there are studies which claim that migration network theory is not able to explain large scale international migration as it ignores a variety of factors leading to migration while also focusing mostly on the supply side and ignoring the demand-side factors (Krissman 2005). Also, network theory has shown not to be equally beneficial in all settings nor across all social groups (Garip and Asad 2015), and it might be losing its importance with the development of technology that leads to more accessible information than in previous periods (Wickramasinghe and Wimalaratana 2016).

Various studies examined the relationship between different political factors and migration. Having in mind East European countries, particularly interesting might be the study made on the sample of respondents in Bosnia and Hercegovina that has shown the political situation as well as conflict and post-conflict experiences as more important factors determining emigration, even more significant than the economic ones (Efendic 2015). Evidence from Kosovo show that political factors were also important in the case of returning migration (Kotorri 2017). Ravlik (2014) findings upon analysing data containing 212 origin and 167 destination countries suggest that migrants are more attracted by countries with common colonial history and also those that show higher Rule of Law index, as well as Human Development index.

Opening of Eastern European economies and the Eastern enlargement has made a significant impact on migration flows from the 'new' to the 'old', more developed member states. Several studies (Fouarge and Ester 2007; Zaiceva and Zimmermann 2008) confirmed that the proportion of individuals intending to emigrate after the 2004 enlargement was more significant in the new member states than in the old member states, indicating to the relevance of the integration enlargement. It is estimated that in the period from 1988 to 2012, about 5.5\% of the population of Southeast and Central Europe left this region (Atoyan et al. 2016).

In the case of East-West EU migration, ethnical similarity and cultural (as well as geographical) proximity makes the migrants from Eastern Europe more desirable in the western countries (Favell 2008). Wage differences of workers with almost the same qualifications in different countries are significantly higher than differences in product prices and the cost of 
capital, which is partly due to the smaller volume of the international labour movement as opposed to capital and product movement (Freeman 2006). Research have shown that in the past decade migrations in Europe were connected to the labour market conditions (Kahanec and Zimmerman 2010) and that the primary migration determinant were not social benefits (Giulietti et al. 2011), which confirms the neoclassical predictions according to which the difference in wages and employment, that is, demand and job offer, along with employment conditions, are key determinants in making individual migration decisions (Massey et al. 1993).

Kahanec, Pytlikova, and Zimmermann (2014) estimated the effects of the EU accession and economic opportunities on migration based on data incorporating immigration flows and foreigner stocks collected by all countries worldwide for 42 destination countries in the period 1980-2010. Applying the difference-indifferences and triple differences estimator, they subsequently find that East-West migration flows in the EU responded positively to the EU entry and economic opportunities in receiving labour markets. However, the authors mainly focus on pull factors such as distance, opening of the labour market and GDP, and do not take into account other economic, social or demographic factors nor do they capture the period after the crisis.

While analysing determinants and shaping factors of labour emigration within the European Union, Son and Noja (2012) developed double-log econometric models that combine cross-section and timeseries in a panel structure by using a set of indicators specific for the emigration process, as well as for the economic activity, labour market, and education, as main explanatory variables. The results of their study show that high unemployment reduces the emigrant stock, mainly due to the loss of associated income and to the reduction of the migrants' capacity to move and integrate into another country. At the same time, a positive selection of emigrants at destination according to their educational level was identified, while an increase in education in the source country downsizes the stock of emigrants mainly due to an improvement in employment perspectives. On the other side, Ganguli (2018) with the micro-level analysis using RoyModel framework for exploring selection of migrants from Russia, Ukraine and Bulgaria to the USA, Spain and Greece, pointed out mostly positive selection in communist and post-communist periods among East European immigrants in the US, while negative selection of these immigrants in the European Union. These differences might be primarily due to the set of countries included in these studies.
Panzaru (2013) analysed several alternative economic factors such as doing business index and the labour market regulation index, as well as indicators that reflect a certain level of freedom and democracy, such as indicators that characterise judicial independence and legal system, but such factors have shown a limited influence on migration in Central and Eastern Europe from 2000 to 2010 . This might be due to potentially non-permanent plans of residing in destination countries but only reaching them to achieve a higher personal wealth in short or medium term or to shortage of this kind of detailed information on destination countries.

Some micro-level studies reveal unmet high expectations of migrants from Eastern Europe to more developed Western countries such as LithuanianIceland study of temporary migration (Minelgaite, Christiansen, and Kristjánsdóttir 2019), is what can affect further developments of migration through return flows even in cases where migrants were planning more temporary migration.

It is often debated that push factors such as unemployment or low wages affect young people the most. However, many young people also choose, or are forced to migrate to escape poverty, violence, conflict, or are displaced due to the effects of war or climate change. As such, young people are heavily represented in migration for humanitarian reasons, including refugees, asylum-seekers and as unaccompanied minors (United Nations 2016), but these reasons are not seen as important in case of the intra-EU migration as in some of the other parts of the world. Nonetheless, there is an overall shortage of empirical research on youth migration determinants.

Young people are a social group that can be particularly affected by different push and pull factors. Recent recession and higher unemployment have shown to cause increasing depression, poor health, higher criminality and suicide rates among the young generation, while at the same time, young and ambitious people are looking for opportunities in foreign countries, creating families there, and thereby, affecting demographic prospects of their home countries (Rakauskienè and Ranceva 2014). In Europe, Baltic and the Mediterranean countries can be denoted as affected the most because young people are emigrating immediately after graduation, which means a loss not only of investment in their education, but also a detriment for the future competitiveness of the country (Rakauskiene and Ranceva 2014).

Van Mol (2016) investigated the influence of micro-and macro-level characteristics on migration aspirations of young people across the EU member states. The results reveal the importance of individual 
characteristics and feelings of discontent with the current climate in explaining emigration aspirations. Furthermore, the author detected a negative relationship between relative welfare levels with emigration aspirations and a positive relationship with the youth unemployment ratio. Together, the results suggest that potential young intra-EU movers are positively selected from the population.

As it can be seen from the presented literature review, there is no consensus on the modelling approach or the variable selection when studying migration determinants. Moreover, migration studies reveal different results depending on the time-frame, sample of countries or methods employed. This paper explores several economic determinants of the contemporary migration flows between new EU member states and older EU member states, covering a period of 18 years, from 2000 to 2017, thus capturing the period prior to and post-global financial crisis. Therefore, the contribution of this paper to the existing empirical literature on determinants of migration is twofold. Namely, the research points out youth unemployment (young population between 15 and 24 years old) as a determinant of migration flows, since young people are a social group that can be particularly affected by different push and pull factors. Also, in the empirical analysis, we use the traditional panel data estimator with time-and-entity-fixed effects to explore the relationship between predictor and outcome variables

\section{DATA AND METHODS}

In this research data form the Eurostat and OECD databases was used. Yearly data on immigrant inflows from 13 new member states (Cyprus, Czech Republic,
Estonia, Hungary, Latvia, Lithuania, Malta, Poland, Slovakia, Slovenia, Bulgaria, Romania and Croatia) to 15 developed European countries (Austria, Belgium, Denmark, Finland, France, Germany, Greece, Ireland, Italy, Luxemburg, Netherlands, Portugal, Spain, Sweden and United Kingdom) was used for the research. More precisely, data on yearly immigrant inflows into 15 developed European countries by country of origin was used for the period from 2000 to 2017. The variable of interest is the emigration rate. Namely, it was empirically tested which determinants affect emigration rate the most. Therefore, explanatory variables are the following: GDP per capita (in PPP) in both destination and origin countries, unemployment rate (in destination and origin countries), the rate of unemployment of young population (in both origin and destination countries) and dummy variable EUmember indicating whether the origin country was a member of the EU in particular year of the analysis. All variables except dummy variable are expressed in natural logarithms, so their coefficient estimates are interpreted as elasticities. Table 1 shows descriptive statistics of analysed variables.

As evident from Table 1, this is an unbalanced panel data set, since the number of observations is not the same for all of the analysed periods.

In a manner of Mayda (2005), we have estimated empirical model that includes emigration rate as the dependent variable, minding the pull and push factors that are on average positive and negative depending on the country of origin or the destination. As the proxy variable for wage in destination and origin countries, we have used GDP per capita in Purchasing Power Parities. In addition, as a determinant of migration flows we have used the rate of unemployment of young population (between 15 and 24 years old) in

Table 1: Descriptive statistics of the variables included in the baseline model (2000-2017)

\begin{tabular}{|l|c|c|c|c|c|}
\hline Variable & $\begin{array}{c}\text { Number of } \\
\text { observations }\end{array}$ & Mean & $\begin{array}{c}\text { Standard } \\
\text { deviation }\end{array}$ & Minimum & Maximum \\
\hline Emigration rate & 2,325 & -9.39 & 1.86 & -14.51 & -4.21 \\
\hline GDP pc in immigration country & 3,510 & 11.40 & 0.28 & 10.87 & 12.34 \\
\hline GDP pc in emigration country & 3,510 & 10.82 & 0.23 & 9.99 & 11.37 \\
\hline Unemployment rate in immigration country & 3,510 & 1.99 & 0.47 & 0.59 & 3.31 \\
\hline Unemployment rate in emigration country & 3,480 & 2.17 & 0.42 & 1.06 & 2.99 \\
\hline $\begin{array}{l}\text { Unemployment rate of young population } \\
\text { immigration country }\end{array}$ & 3,509 & 2.84 & 0.51 & 1.72 & 4.07 \\
\hline $\begin{array}{l}\text { Unemployment rate of young population in } \\
\text { emigration country }\end{array}$ & 3,510 & 2.99 & 0.40 & 2.07 & 3.91 \\
\hline Dummy variable EUmember & 3,492 & 0.71 & 0.45 & 0 & 1 \\
\hline
\end{tabular}

Note: all the variables are expressed in natural logarithms, except the dummy variable EUmember 
both origin and destination countries. Our model is a fixed effect panel model, so we have employed country and time specific effects to avoid biased estimates. Also, our regressions have robust standard errors clustered by country pair (destination and origin country), to address heteroscedasticity and allow for correlation over time of country pair observations. The baseline empirical model of the determinants of immigration flows is the following:

$$
\begin{aligned}
& \ln _{\text {emrate }_{i j t}}=\beta_{0}+\beta_{1} \ln G D P p c_{i t-1}+ \\
& \beta_{2} \ln G D P p c_{j t-1}+\beta_{3} \ln \text { unemployment }{ }_{i}+ \\
& \beta_{4} \ln \text { unemployment }_{j}+\beta_{5} \ln \text { unempyoung }_{i}+ \\
& \beta_{6} \ln \text { unempyoung }_{j}+\text { DEUmember }+\delta I_{t}+\varepsilon_{i j t}
\end{aligned}
$$

where $i$ is the origin country, $j$ is the destination country, and $t$ is the time. lnemrate $i_{i j t}$ is the logarithm of emigration rate from $i$ to $j$ at time $t . \ln G D P_{p c}$ is the $(\ln )$ per worker GDP, PPP-adjusted. lnunemployment is the (ln) unemployment rate and lnunempoyoung is the (ln) unemployment rate of young (15-24). DEUMember is the dummy variable that equals 1 if the country of origin is the member of EU at the analysed time (2000-2017). Finally, the baseline model also includes destination and origin countries' fixed effects and year effects. In order to account for endogeneity in time series dimension, we used lagged values of (ln) GDP per capita in both, destination and origin country.

\section{RESULTS OF THE EMPIRICAL ANALYSIS}

Presented Table 2 contains the estimation results of the baseline model given by the equation 1 . The estimates are broadly consistent with the theoretical predictions of the international migration model.

According to the presented results, the elasticity of emigration rate to changes in GDP per capita in destination country is statistically significant and positive with the coefficient being 3.41. Furthermore, the elasticity of emigration rate to changes in GDP per capita in origin country is also statistically significant and positive, but the coefficient is much smaller (0.96). The unemployment rate in origin country is positive and statistically significant (on 5\% significance level) with the elasticity of 0.4563 . Youth unemployment is often examined separately because it tends to be higher than unemployment in older age groups. It usually comprises of labour force aged 15 to 24 years old. According to our baseline model, the elasticity of emigration rate to changes in unemployment rate of young population is negative and statistically significant in the case of destination country (coefficient is -0.89), and it is negative, but not statistically significant in the case of origin country. It is also important to emphasise that the used Eurostat data on youth unemployment includes only those young people that are in the labour market and not the proportion of all unemployed young adults. Furthermore, the dummy variable EUmember is statistically significant and positive (in the case that the origin country is a member of the EU).

Empirical results are due to specific statistical methodology that was used, and they are somewhat exploratory in their nature. However, they are partially

\begin{tabular}{|c|c|}
\hline $\begin{array}{l}\text { Dependent variable: } \\
\text { Ln Emigration rate }\end{array}$ & \multirow[t]{2}{*}{ NMS } \\
\hline Independent variables: & \\
\hline Ln GDP pc in immigration country $(t-1)$ & $\begin{array}{c}3.409 * * * \\
{[0.685]}\end{array}$ \\
\hline Ln GDP pc in emigration country $(t-1)$ & $\begin{array}{c}0.9559 * * * \\
{[0.3466]}\end{array}$ \\
\hline $\begin{array}{l}\text { Ln Unemployment rate in immigration } \\
\text { country }\end{array}$ & $\begin{array}{l}0.3478 * \\
{[0.1789]}\end{array}$ \\
\hline $\begin{array}{l}\text { Ln Unemployment rate in emigration } \\
\text { country }\end{array}$ & $\begin{array}{l}0.4563^{* *} \\
{[0.2245]}\end{array}$ \\
\hline $\begin{array}{l}\text { Ln Unemployment rate of young } \\
\text { population immigration country }\end{array}$ & $\begin{array}{c}-0.8945^{* * *} \\
{[0.2413]}\end{array}$ \\
\hline $\begin{array}{l}\text { Ln Unemployment rate of young } \\
\text { population in emigration country }\end{array}$ & $\begin{array}{l}-0.1005 \\
{[0.2143]}\end{array}$ \\
\hline Dummy variable EUmember & $\begin{array}{c}0.6681^{* * *} \\
{[0.0753]}\end{array}$ \\
\hline Time fixed effects & $\begin{array}{c}0.0326^{* * *} \\
{[0.0089]}\end{array}$ \\
\hline Constant & $\begin{array}{c}-123.449 * * * \\
{[14.2702]}\end{array}$ \\
\hline Number of observations & 2,171 \\
\hline Number of groups (countries) & 157 \\
\hline R square & 0,5369 \\
\hline$F(8,156)$ & $81.81^{* * *}$ \\
\hline
\end{tabular}

Table 2: Fixed effects panel model of the determinants of immigration flows from the new member states (20002017) 1

Note: the estimated empirical model is a panel model with pair of country fixed effects and time fixed effects; robust standard errors clustered at the country-pair level are given in parenthesis; ${ }^{* *},{ }^{* *}$ and ${ }^{*}$ denote $1 \%, 5 \%$ and $10 \%$ significance level, respectively.

1 All relevant diagnostic tests for the estimated baseline model were conducted. They are not shown here in order to save space, but are available from the authors upon the request. 
consistent with Mayda (2005) where the emigration rate is positively related to the destination country per worker GDP, but the impact of income opportunities change at home on the emigration rate was found to be insignificant. The share of the young population in the origin country has a positive and significant impact on emigration rates, but Mayda defined young people as a group from 15-29 years old. Grau Grau and Ramirez Lopez (2017) found that GDP per capita and GDP growth behave similarly, with reasonably high significance levels $(5 \%)$. The positive nature and size of the coefficients indicate that they are decisive for migration flow and positively affect growth in the numbers of immigrants entering Europe.

In the EU, unemployment has been on the rise since 2008 , which is due to the economic crisis which caused considerable job loss, fewer job offerings, and consequently, a rise of the unemployment rate. Older workers are struggling to find new jobs despite their experience, and young graduates are struggling to find new jobs because there are no new workplaces created (Statista 2018). Following the results of this research which indicate that young population unemployment rate in the immigration country is significant and negatively correlated with the emigration rate, it can be concluded that lower unemployment rates are an important pull factor of migration. If there are no jobs for young people in the country of origin, they will look for better opportunities abroad, where youth unemployment is decreasing.

The estimation results from our migration model suggest that emigration rate responds rather quickly to changes in GDP per capita and the youth unemployment rate in immigration country. Thus, international migration contributes significantly to adjusting the labour supply to fluctuations in economic activity.

\section{CONCLUDING REMARKS}

The primary objective of this paper was to study determinants of migration flows from the 'new' EU member states to the 'old' member states that differ significantly in economic and other properties. The emphasis was given to youth unemployment in both origin and destination countries since young people are a social group that can be particularly affected by different push and pull factors. However, there is a lack of empirical evidence on the importance of this factor to migration flows.

In the empirical part of this analysis, the traditional panel data estimator with time and country fixed effects was used to explore the relationship between emigration rate and the set of economic explanatory variables: GDP per capita (in PPP) in both destination and origin countries, unemployment rate (in destination and origin countries), the rate of unemployment of young population (in both origin and destination countries) and dummy variable EUmember. The data set covered the period from 2000 to 2017, capturing the period of the global financial crisis as well as postcrisis period for all analysed countries.

The results have shown that GDP per capita is a significant migration determinant with a positive sign in both the emigration and immigration countries, but it can be concluded that migrants are more motivated by the increase in the GDP per capita in the immigration country than in the country of origin. Results also reveal that the increase in the overall unemployment rate in the emigration country will increase the emigration rate. Furthermore, research indicates that young people are motivated by the perceived labour market opportunities in the immigration country measured by the youth unemployment rate. Also, dummy variable EUmember has shown to affect migration, although not all EU countries allowed free movement of labour from the new member states immediately after their accession.

Accordingly, the estimation results suggest that emigration rate responds quickly to changes in GDP per capita and unemployment rate of the young population in the immigration country. Thus, international migration contributes significantly to adjusting the labour supply to fluctuations in economic activity. The results of the analysis enable a better understanding of migration flows determinants, as an essential prerequisite for estimating future migration flows and their overall potential effects on origin and destination countries.

Given the scale of emigration that new member states have experienced since joining the EU, some policy recommendations for these countries and other candidate countries can be drawn down from this study. As low levels of young population unemployment have shown to be an important pull factor, which can be a result of the perceived employment opportunities in more developed countries, it is essential not only to address the youth unemployment levels, but also their status and development prospects in countries of origin. Young people are drivers of change in the society and are especially important in ageing societies of Europe. Upon their emigration, countries of origin lose their investment in educating them and also lose a part of innovation capabilities that younger population takes to destination countries upon migration.

In order to reveal key determinants leading young people to migrate in detail, more research on this 
topic is needed. Therefore, further research on push and pull factors within the youth population could be of great interest in both origin and destination countries. Availability of the statistical data on young population immigration by countries of origin would enable further research of migration determinants of this age group. Since in this study, a rather simple panel data model was used, implications for policy makers are not detailed nor exhaustive. However, the taken panel approach could inspire future studies that would reveal more details on the migration flows determinants with special attention given to immigration of young population.

\section{REFERENCES}

Atoyan, M. R., Christiansen, L. E., Dizioli, A., Ebeke, M. C., Ilahi, M. N., Ilyina, M. A., and Raei, M. F. 2016. Emigration and its economic impact on Eastern Europe. International monetary fund. Discussion Note SDN 16/07. https://www.imf. org/external/pubs/ft/sdn/2016/sdn1607.pdf (accessed January 15, 2019).

Doğan, D., Gizem, M., and Kabadayı, A. 2015. Determinants of Internal Migration in Turkey: A Panel Data Analysis Approach. Border Crossing 5 (1-2): 16-24.

Dorigo, G. and Tobler, W. 1983. Push-pull migration laws. Annals of the Association of American Geographers 73 (1): 1-17.

Efendic, A. 2016. Emigration intentions in a post-conflict environment: evidence from Bosnia and Herzegovina. Post-Communist Economies 28 (3): 335-352.

Eurostat. 2019. (database online). https://ec.europa.eu/eurostat/ (accessed January 7, 2019).

Fan, S. and Stark O. 2007. The brain drain, educated unemployment, human capital formation, and economic betterment. Economics of transition 15 (4): 629-660.

Favell, A. 2008. The new face of East-West migration in Europe. Journal of ethnic and migration studies 34 (5): 701-716.

Fouarge, D. and Ester, P. 2007. Factors determining international and regional Migration in Europe. European Foundation for the Improvement of Living and Working Conditions. Dublin.

Ganguli, I. 2018. Immigrant selection before and after communism. Economics of Transition 26 (4): 649-694.

Garip, F. and Asad, A. L. 2015. Migrant networks. Emerging Trends in the Social and Behavioral Sciences: An Interdisciplinary, Searchable, and Linkable Resource. Harvard University.

Giulietti, C., Guzi, M., Kahanec, M., and Zimmermann, K. F. 2011. Unemployment benefits and immigration: Evidence from the EU. IZA Discussion Papers No. 6075.
Institute for the Study of Labor (IZA), Bonn. http://ftp.iza. org/dp6075.pdf (accessed January 22, 2019).

Grau Grau, A. and Ramirez Lopez, F. 2017. Determinants of Immigration in Europe. The Relevance of Life Expectancy and Environmental Sustainability. Sustainability 9 (1093): 1-17.

Hatton, T. J. and Williamson, J. G. 2005. Global migration and the world economy: Two centuries of policy and performance. Cambridge, MA: MIT press.

Haug, S. 2008. Migration networks and migration decisionmaking. Journal of Ethnic and Migration Studies 34 (4): 585-605.

Jurčić, Lj. and Barišić, A. 2018. Determinants, trends and implications of modern migration. Paper presented at The traditional consultation of the Croatian Society of Economists: Economic Policy of Croatia, Opatija, November.

Kahanec, M. and Zimmermann, K. F. 2011. High-Skilled Immigration Policy in Europe. Discussion Paper No. 1096. Institute for the Study of Labor (IZA), Bonn. http://ftp.iza. org/dp5399.pdf (accessed January 15, 2019).

Kahanec, M., Pytlikova, M., and Zimmermann, K. F. 2014. The Free Movement of Workers in an Enlarged European Union: Institutional Underpinnings of Economic Adjustment. IZA Discussion Papers No. 8456. Institute for the Study of Labor (IZA), Bonn. https://pdfs.semanticscholar.org/36bd/759457ed9a37dd52580e3e9258cfa 8ce7d68.pdf (accessed January 15, 2019).

Kim, K. and Cohen, J. E. 2010. Determinants of International Migration Flows to and from Industrialized Countries: A Panel Data Approach Beyond Gravity. International migration review 44 (4): 899-932.

Kleven, H., Landais, C., Muñoz, M., and Stantcheva, S. 2019. Taxation and Migration: Evidence and Policy Implications. National Bureau of Economic Research No. w25740.

Kotorri, M. 2017. The probability of return conditional on migration duration: evidence from Kosovo. South East European Journal of Economics and Business 12 (2): 35-46.

Krissman, F. 2005. Sin coyote ni patron: why the "migrant network" fails to explain international migration. International migration review 39 (1): 4-44.

Lee, E. S. 1966. A theory of migration. Demography 3 (1): 47-57.

Levitt, P. and Lamba-Nieves, D. 2011. Social remittances revisited. Journal of Ethnic and Migration Studies 37 (1): 1-22.

Liu, M. M. 2013. Migrant networks and international migration: Testing weak ties. Demography 50 (4): 1243-1277.

Mansoor, A. and Quillin, B., eds. 2006. Migration and remittances: Eastern Europe and the Former Soviet Union (chapter 3). Washington: World Bank.

Massey, D., Arango, J., Hugo, G., Kouaouci, A., Pellegrino, A., and Taylor, J. 1993. Theories of International Migration: 
A Review and Appraisal. Population and Development Review 19 (3): 431- 466.

Mayda, A. M. 2005. International Migration: A Panel Data Analysis of Economic and Non-Economic Determinants. Discussion Paper No. 1590. The Institute for the Study of Labor, IZA, Bonn. http://ftp.iza.org/dp1590.pdf (accessed January 15, 2019).

Mayda, A. M. 2010. International migration: A panel data analysis of the determinants of bilateral flows. Journal of Population Economics 23 (4): 1249-1274.

Meyer, J. B. 2001. Network approach versus brain drain: lessons from the diaspora. International migration 39 (5): 91-110.

Minelgaite, I., Christiansen, P. H., and Kristjánsdóttir, E. S. 2019. Lithuanian temporary workers in Iceland in another economic boom: Expectations and experiences. The South East European Journal of Economics and Business 14 (1): 101-114.

OECD. 2019. International Migration Database (database online). https://stats.oecd.org/Index. aspx?DataSetCode=MIG (accessed January 7, 2019).

Oh, Y. and Jung, J. 2013. Determinants of International Labor Migration to Korea. KIEP Research Paper No. 1308. http://dx.doi.org/10.2139/ssrn.2452880 (accessed February 25, 2019).

Panzaru, C. 2013. The Determinants of International Migration. A Panel Data Analysis. Journal of Politics and Law 6 (1): 142-148.

Rakauskienė, O. G. and Ranceva, O. 2014. Youth unemployment and emigration trends. Intellectual Economics 8 (1): 165-177.
Ravlik, M. 2014. Determinants of international migration: a global analysis. Working papers series WP BRP 52/ SOC/2014. National Research University Higher School of Economics. https://www.hse.ru/data/2014/10/02/11 00265067/52SOC2014.pdf (accessed February 15, 2019).

Son, L. and Noja, G. G. 2012. A macroeconometric panel data analysis of the shaping factors of labour emigration within the European Union. Theoretical and Applied Economics 11 (576): 15-30.

Statista. 2018. Youth unemployment rate in EU member states as of December 2018. https://www.statista.com/ statistics/266228/youth-unemployment-rate-in-eucountries/ (accessed February 25, 2019).

Sulaimanova, B. and Bostan, A. 2014. International Migration: A Panel Data Analysis of the Determinants of Emigration from Tajikistan and Kyrgyzstan. Eurasian Journal of Business and Economics 7 (13): 1-9.

United Nations. 2016. Youth and migration. UN policy brief. UN Department of Economic and Social Affairs. https:// www.un.org/esa/socdev/documents/youth/fact-sheets/ youth-migration.pdf (accessed 25 February, 2019).

Van Mol, C. 2016. Migration aspirations of European youth in times of crisis. Journal of Youth Studies 19 (8): 1303-1320.

Zaiceva, A. and Zimmerman, K. F. 2008. Scale, diversity, and determinants of labour migration in Europe. Oxford Review of Economic Policy 24 (3): 427-451.

Zhao, Y. 2003. The role of migrant networks in labor migration: The case of China. Contemporary Economic Policy 21 (4): 500-511.

Wickramasinghe, A. A. I. N. and Wimalaratana, W. 2016. International migration and migration theories. Social Affairs 1 (5): 13-32. 